\title{
HIV and Human Coronavirus Coinfections: A Historical Perspective
}

\author{
Palesa Makoti and Burtram C. Fielding * \\ Molecular Biology and Virology Research Laboratory, Department of Medical Biosciences, University of the \\ Western Cape, Cape Town 7535, South Africa; 3062559@myuwc.ac.za \\ * Correspondence: bfielding@uwc.ac.za; Tel.: +27-21-959-2949
}

Received: 21 May 2020; Accepted: 2 August 2020; Published: 26 August 2020

\begin{abstract}
Seven human coronaviruses (hCoVs) are known to infect humans. The most recent one, SARS-CoV-2, was isolated and identified in January 2020 from a patient presenting with severe respiratory illness in Wuhan, China. Even though viral coinfections have the potential to influence the resultant disease pattern in the host, very few studies have looked at the disease outcomes in patients infected with both HIV and hCoVs. Groups are now reporting that even though HIV-positive patients can be infected with hCoVs, the likelihood of developing severe CoV-related diseases in these patients is often similar to what is seen in the general population. This review aimed to summarize the current knowledge of coinfections reported for HIV and hCoVs. Moreover, based on the available data, this review aimed to theorize why HIV-positive patients do not frequently develop severe CoV-related diseases.
\end{abstract}

Keywords: coronaviruses; HIV; COVID-19; SARS-CoV-2; MERS-CoV; immunosuppression; immune response; coinfection

\section{Introduction}

With the rapid advancement of molecular diagnostic tools, our understanding of the etiological agents of respiratory tract infections (RTIs) has advanced rapidly [1]. Researchers now know that lower respiratory tract infections (LRTIs) — caused by viruses-are not restricted to the usual suspects, such as respiratory syncytial virus (RSV), parainfluenza viruses (PIVs), adenovirus, human rhinoviruses (HRVs) and influenza viruses. Interestingly, the other causative viral agents typically have similar seasonal incidence and clinical presentations as the more "common" viruses [2,3].

With the third deadly human coronavirus (hCoV)-SARS-CoV-2 (Severe acute respiratory syndrome coronavirus-2 or SARS-2) - recently identified in China [4,5], the role of coronaviruses (CoV) in respiratory tract infections is once again under the spotlight. Human CoVs were first isolated and identified in the 1960s, first hCoV-OC43 (OC43) [6] and then hCoV-229E (229E) [7]. Only after the global outbreak of severe acute respiratory syndrome (SARS) was linked to the novel SARS-CoV [8], did the attention shift back to the hCoVs. Since then, researchers have identified NL63-CoV (NL63) [9], HKU1-CoV (HKU1) [10], and MERS-CoV (Middle Eastern respiratory syndrome coronavirus, or MERS) [11,12] as agents of both upper respiratory tract infections (URTIs) and LRTIs.

In most cases, infection with the four "common" HCoVs (229E, OC43, NL63 and HKU1) causes mild cold-like symptoms, involving the upper respiratory tract. A severe LRTI can, however, develop in immunocompromised patients and children [13]. Unlike the common hCoVs, the more pathogenic SARS, MERS and SARS-2 frequently cause more severe LRTI. In some patients, the infection is accompanied by a cytokine storm, which can lead to a poor prognosis [14].

For a long time, researchers have looked at a clinical syndrome as the result of an infection by a single virus. Now we know that, even though viral interference (one virus competitively suppresses the 
replication of other coinfecting viruses) is the most common outcome of viral coinfections, these types of infection have the potential to influence the resultant disease pattern in the host [15].

Whereas, "coinfection" refers to the simultaneous infection of a cell or host by separate viruses [16], "superinfection" refers to a scenario where one virus infects the host some time before infection by the second virus. For both of these, the fate of the virus-infected host often depends on the balance between the host's protective immunity and immunopathology $[17,18]$. In the context of human immunodeficiency virus (HIV) infections, however, superinfections refer to the phenomenon where an HIV infected person is infected with a subsequent distinct HIV viral strain [19]. Therefore, this manuscript will use the term "coinfection" when referring to the relationship between HIV and hCoVs in the infected host.

This review aimed to summarize the current knowledge of coinfections reported for hCoVs and HIV. Also, based on the data available, we aimed to theorize why HIV-positive patients do not frequently develop severe CoV-related disease.

\section{HIV-hCoV Coinfections}

Due to the lack of published academic work for $\mathrm{HIV} / \mathrm{hCoV}$ coinfections, not much is known about the clinical and epidemiological outcomes in patients with HIV and hCoV coinfections. It is not clear whether this lack of published data is due to the lack of screening for the hCoVs, or whether the hCoVs are just not present frequently in HIV-positive patients. During the current coronavirus pandemic, this lack of information is a concern in countries with high HIV cases, especially in Sub-Saharan Africa-where $70 \%$ of people living with HIV are found [20].

Historically, the four common hCoVs are also known to cause gastrointestinal problems in HIV-positive individuals. Unfortunately, since this was before the advent of sophisticated diagnostic tools, electron microscopy was used to identify the presence of coronavirus-like particles (CVLPs) and little is known about the specific hCoVs present in the stool samples from these HIV-positive patients. Moreover, even though these are studies reporting on the findings from small HIV-positive cohorts, between $14-50 \%$ of participant's stool samples were observed to contain CVLPs; for all of these, bar one patient, there was no correlation with enteric symptoms [21,22]. Therefore, from the late 1980s, human coronaviruses were speculated to be agents of opportunistic infections in immunocompromised hosts, and possible causative agents of diarrheal disease in AIDS [21]. More recently, it has been reported that these hCoVs can also cause more severe RTIs in HIV-positive individuals (Table 1); traditionally, CoVs were not even considered as a cause of RTIs in HIV-positive individuals [23].

One such study reports a 32-years old, HIV positive male, who tested positive for hCoV-229E and RSV. This patient was admitted with acute respiratory failure and died of multiorgan failure 14 days after admission to the intensive care unit (ICU). At the time of admission, the patient was not on any antiretroviral treatment (ART); he was only started on combination ART with a regimen of abacavir, lamivudine and efavirenz after testing positive for HIV [24].

Another study reports the detection of hCoV in HIV-positive children with LRTIs. Testing 517 samples, the authors reported the presence of different types of respiratory viruses in $60.9 \%$ of children. Interestingly, OC43, NL63 and HKU1 were detected at varying incidence in clinical samples, with $12.2 \%, 1.7 \%$ and $1.4 \%$, respectively. Importantly, $70 \%$ of HIV-negative children with LRTIs also tested positive for respiratory viruses, including hCoVs [25], showing that this is a problem in all children.

How do the three pathogenic hCoVs behave in HIV-positive patients (Table 1)? According to our knowledge, only one reported case study of an HIV-positive person infected with SARS-CoV is available. The 30-year-old male developed relatively mild symptoms, including chest pain and chills, fever, dry cough and general malaise, but recovered fully from SARS [26]. During the same period, another study reported the connection between HIV and SARS-CoV. Interestingly, despite contact between 95 SARS-confirmed patients and 19 HIV-positive individuals in a hospital ward, none of the HIV-positive patients became infected with the SARS-CoV. However, six of 28 medical personnel who worked in the same ward were infected with the SARS-CoV [27]. 
Researchers are now also reporting cases of HIV/SARS-CoV-2 coinfection. A study of a 61-year-old male from Wuhan, China is one of the first cases reported; this patient had type II diabetes and mild lymphopenia, and is a heavy smoker. The patient was placed on oral therapy with the anti-HIV drug, lopinavir/ritonavir on admission. He recovered fully and was discharged 20 days after first reporting to the local fever clinic [28].

A group from Spain, reports HIV/SARS-CoV-2 coinfections in five individuals-three male and two transgender patients. When the patients presented to the hospital, two had URTIs, and three viral pneumonia. Furthermore, one patient had hypothyroidism, and another asthma as co-morbidities. On admission to hospital, four of the patients were on HIV ARTs; two were using a protease-inhibitor (darunavir-boosted cobicistat), and two were using an integrase-inhibitor (dolutegravir). Additionally, all five patients were started on SARS-CoV-2 boosted-protease inhibitor ART on the day of coronavirus disease-19 (COVID-19) diagnosis. Initially, two patients were admitted to ICU, but one recovered and was released from ICU; the remaining patient remains in ICU. So, at the time of reporting, four of the patients recovered and were discharged [29].

An observational prospective study from Spain (Madrid) reports 51 (eight women, 43 men) SARS-CoV-2-positive cases (35 laboratory-confirmed; 16 suspected cases) among a cohort of 2873 HIV-positive individuals (an incidence 1.8\%). Interestingly, these HIV/SARS-CoV-2 patients presented similar clinical, laboratory and radiographical features reported for HIV-negative patients infected with SARS-CoV-2. The authors reported that among HIV-positive individuals, those with COVID-19 has a significantly higher prevalence of co-morbidities ( 32 or $63 \%$, mostly hypertension and diabetes) compared with those without COVID-19 (495 or 38\%). For this cohort, 37 (73\%) patients were receiving nucleoside reverse transcriptase inhibitors (NRTIs), and $11(22 \%)$ had previous protease inhibitor treatment before COVID-19 diagnosis. The SARS-CoV-2-positive cohort included 12 mild, 38 mild-to-moderate and 13 severe COVID-19 cases. At the time of reporting, 44 COVID-19 patients recovered, six patients were still critically ill, and two patients died [30].

Another study from Wuhan, China looked at 1174 HIV-positive people. This group reports eight (seven males; one female) COVID-19 symptomatic patients, of which six were laboratory- and two clinically-confirmed. On admission, all eight HIV/SARS-2 patients were on ARTs (NRTIs and Non-Nucleoside Reverse Transcriptase Inhibitors). Of the eight patients, six had mild symptoms; two had severe symptoms, resulting in one fatality. Unfortunately, this group does not report any co-morbidities for the eight patients. Interestingly, another nine HIV/AIDS patients had close contact with laboratory-confirmed COVID-19 patients, but only one of them tested positive for COVID-19; this person was asymptomatic for COVID-19. At the time of reporting, this patient had Kaposi's sarcoma and was receiving chemotherapy [31].

A group from Turkey studied 1224 HIV-positive individuals. They report only four HIV/SARS-CoV-2 coinfected male patients, of which three had no co-morbidities and made a full recovery. All three patients were on HIV ARTs and developed mild COVID-19 symptoms. The fourth patient, a 44-year-old with co-morbidities, including hypertension, diabetes, chronic obstructive pulmonary disease (COPD) and obesity, died. This patient was on ARTs, his HIV viral load was low, and his $\mathrm{CD}^{+}$cell count was high before he contracted COVID-19 [32].

Zhao et al., reports the case of a 38-year-old man with fever, accompanied by muscle aches, who was admitted to hospital in Shenzhen, China. The patient had a travel history to Wuhan during the SARS-CoV-2 outbreak, but no other COVID-19 symptoms were observed on physical examination. Computerized tomography (CT) scans showed right lower pneumonia, for which oseltamivir and interferon (IFN)-alpha inhalation were administered. He had a normal white blood cell, lymphocyte and platelet count. Even though the patient tested negative for SARS-CoV-2 by reverse transcription-polymerase chain reaction (RT-PCR) at different time points, he tested positive for the presence of SARS-CoV-2-specific antibodies 40-days later. On admission to hospital, the patient was using antiretrovirals (lamivudine, tenofovir, and efavirenz) for an HIV/Hepatitis C (HCV) coinfection. 
His close contact partner, also with HIV-1 infection, who was also taking anti-HIV agents, tested negative for SARS-CoV-2 RNA throughout the study [33].

The first reported case of HIV/SARS-CoV-2 coinfection from sub-Saharan Africa (specifically Uganda), involves a 34-year-old HIV-positive woman. On the day of admission, the patient reported a recent travel history to Italy, but was otherwise healthy and reported no COVID-19-associated symptoms. Even though the patient showed no respiratory symptoms, she developed gastrointestinal symptoms. Then, three days after admission, she developed a headache, chest pain, anorexia and muscle aches, but still no cough or shortness of breath. Prior to contracting COVID-19, she was using ARTs (tenofovir disoproxil fumarate, lamivudine and efavirenz) for five years and she had no other recorded co-morbidities. The patient made a full recovery and was discharged on day 24 [34].

In one of the largest clinical case studies describing the clinical characteristics and outcomes in HIV/SARS-CoV-2 patients_-from New York City (USA)—2159 adult patients (older than 18 years old) with laboratory-confirmed COVID-19 were admitted to hospital in a one-month period. Thirty-one of these patients (or 1.4\%) were HIV-1 positive. In the HIV/SARS-CoV-2 cohort, at least one co-morbidity was observed in $22(71 \%)$ patients, with hypertension in $21(67.7 \%)$, diabetes mellitus in $13(41.9 \%)$ and obesity in nine (33.3\%) patients. Moreover, eight (25.8\%) were diagnosed with asthma or COPD. Before hospital admission, all patients were on ARTs, with an integrase inhibitor-based triple therapy used by 20 patients. Interestingly, COVID-19-associated symptoms were similar to the commonly reported ones for the HIV-negative population, with 23 patients $(74.2 \%)$ presenting with fever or developing fever following admission. For this group, one patient developed mild, two moderate, 21 severe, and seven critical symptoms. At the time of reporting, eight patients had died (four had "do not resuscitate" orders), but $21(67.7 \%)$ recovered and were discharged $-13(41.9 \%)$ home and eight $(25.8 \%)$ to a care facility - and two were still hospitalized. All eight mortalities were older than 50 years old, and seven of the eight were using a tenofovir prodrug as part of their ART treatment [20]. Similarly, a large study of 5700 COVID-19-positive patients admitted to a network of New York City hospitals reports only 48 HIV-positive patients (prevalence of $0.8 \%$ ). Unfortunately, not much is reported for these patients as their HIV status was merely reported as a co-morbidity [35].

Gervasoni et al. (2020) describe $47 \mathrm{HIV}$-positive patients with laboratory-confirmed (28, including one asymptomatic patient) or probable (19) SARS-CoV-2 infection; these were identified out of 6,000 HIV-positive patients. Almost $64 \%$ of the 47 HIV/SARS-CoV-2 patients had at least one co-morbidity (mainly dyslipidemia, arterial hypertension and Hepatitis B virus (HBV) or HCV coinfections). At the time of hospitalization, 38 of the patients were on an integrase inhibitor-based ART and 5 a protease inhibitor-based treatment; 20 were receiving a tenofovir-based regimen. The COVID-19 diagnosis of the probable cases was based on their clinical symptoms and the presence of risk factors (mainly being healthcare workers or contact with confirmed COVID-19 patients). Thirteen of the 28 laboratory-confirmed SARS-CoV-2 positive patients were hospitalized, six with severe lung disease, of which two required mechanical ventilation. At the time of reporting, 45 patients made a full recovery. Two fatalities were reported: A 47-year-old overweight man without other co-morbidities, and another patient with confirmed cardiovascular disease and a recent diagnosis of lung cancer [36].

Benkovic et al. (2020) report the case studies of four HIV/SARS-CoV-2 coinfected patients. All four patients had uncomplicated cases of SARS-CoV-2 infection, with symptoms commonly reported by the general population, including fatigue, loss of taste and smell, fever and cough. Co-morbidities were recorded for all four, with atrial fibrillation, hyperlipidemia, hypertension, type II diabetes mellitus and treated HCV listed. At the time of testing, all four patients were using ARTs (four were using NRTIs, three were using integrase strand transfer inhibitors, one was using a CCR5 antagonist, one was using non-nucleoside reverse transcriptases, and one was using a CYP3A inhibitor) and all had robust CD4 ${ }^{+}$ $\mathrm{T}$ cell counts. Three of the patients were asked to home self-isolate, and the fourth was hospitalized; the latter was also positive for an influenza A test. At the time of reporting, all four patients recovered from COVID-19 [37]. 
Table 1. Human coronavirus infections in HIV-positive patients.

\begin{tabular}{|c|c|c|c|c|c|c|c|}
\hline Study Cohort & $\begin{array}{l}\mathrm{hCoV}(\% \\
\text { Incidence) }\end{array}$ & Clinical Presentation & $\begin{array}{l}\text { Other Types of Drugs } \\
\text { Administered (Number } \\
\text { Receiving the Drug) }\end{array}$ & $\begin{array}{l}\text { Disease Outcome } \\
\text { at the Time of } \\
\text { Reporting }\end{array}$ & Co-Morbidities & Other Pathogens & Reference \\
\hline $\begin{array}{l}\text { Thirty-two-year } \\
\text { old male }\end{array}$ & $229 \mathrm{E}$ & $\begin{array}{c}\text { Acute respiratory failure, } \\
\text { respiratory distress, cough, fever, } \\
\text { tachypnea, low } \mathrm{CD} 4^{+} \text {count, high } \\
\text { HIV RNA count, pneumonia, acute } \\
\text { renal failure, anemia, } \\
\text { thrombocytopenia, elevated } \\
\text { C-reactive Protein levels }\end{array}$ & $\begin{array}{c}(\mathrm{ART}) \\
\text { NRTIs, antibiotics, } \\
\text { high dose norepinephrine } \\
\text { infusion }\end{array}$ & $\begin{array}{l}\text { Fatal multi-organ } \\
\text { failure }\end{array}$ & None reported & $\begin{array}{c}\text { RSV, E. coli, Proteus } \\
\text { mirabilis }\end{array}$ & [24] \\
\hline $\begin{array}{l}\text { Five hundred and } \\
\text { seventeen samples } \\
\text { from children }\end{array}$ & $\begin{array}{l}\text { OC43 }(12.2 \%) ; \\
\text { NL63 }(1.7 \%) ; \\
\text { HKU1 }(1.4 \%)\end{array}$ & $\begin{array}{c}\text { Cyanosis }(11.4 \% \text { vs. } 8.1 \%), \\
\text { CXR-AC (Pneumonia- } 26.6 \% \text { vs. } \\
\text { 22.1\%), C-reactive protein (CRP) } \\
\text { levels (15 vs. } 12 \mathrm{mg} / \mathrm{mL}) \text {, fever }\end{array}$ & $\begin{array}{c}\text { PCV9 } \\
\text { (pneumococcal vaccine) }\end{array}$ & Not reported & None reported & $\begin{array}{c}\text { hRV }(31.7 \%), \\
\text { human bocavirus }(9.5 \%), \\
\text { polyomavirus WUPyV } \\
(8.9 \%) \\
\text { Bacteria }\end{array}$ & [25] \\
\hline $\begin{array}{l}\text { Thirty-year old } \\
\text { male }\end{array}$ & SARS-CoV & $\begin{array}{l}\text { Low } \mathrm{CD} 4^{+} \text {count, high HIV RNA } \\
\text { count, dry cough, fever and } \\
\text { malaise, pneumonia, tachypnea, } \\
\text { lymphopenia, }\end{array}$ & $\begin{array}{c}\text { (HAART) } \\
\text { NRTIs, Protease inhibitors, } \\
\text { Pneumocystis carinii } \\
\text { pneumonia prophylaxis, } \\
\text { Ribavin + prednisolone } \\
\text { (anti-SARS), anti-TB } \\
\text { treatment }\end{array}$ & Full recovery & ТВ & HBV & [26] \\
\hline $\begin{array}{l}\text { Sixty-one-year old } \\
\text { male }\end{array}$ & SARS-2 & $\begin{array}{l}\text { Dry cough, lymphopenia, } \\
\text { pneumonia, dypsnea }\end{array}$ & $\begin{array}{c}\text { Aloglibtin + Metformin, } \\
\text { protease inhibitors, } \\
\text { antibiotics, } \\
\text { immunosuppresants }\end{array}$ & Full recovery & Type II diabetes & None reported & [28] \\
\hline $\begin{array}{l}\text { Three cisgender } \\
\text { men, } 2 \\
\text { transgender } \\
\text { people }\end{array}$ & SARS-2 & $\begin{array}{c}\text { Fever, low CD4 }{ }^{+} \text {count }(1 / 5) \text {, high } \\
\text { HIV RNA load }(1 / 5) \text {, elevated CRP } \\
\text { levels }(4 / 5) \text {, elevated ferratin levels } \\
\text { (3/5), lymphocytopenia }(2 / 5), \\
\text { thrombocytopenia, cough, LRTI } \\
\text { (3/5), URTI }(2 / 5) \text {, cough }\end{array}$ & $\begin{array}{l}\text { ARTs, hydroxychloroquine } \\
\text { (4), IFN beta- } 1 \mathrm{~b}(2), \\
\text { antbiotic, corticosteroids (2), } \\
\text { immunosuppresants (1) }\end{array}$ & $\begin{array}{l}\text { Four recovered; } 1 \\
\text { in ICU }\end{array}$ & $\begin{array}{l}\text { Hypothyroidism } \\
\text { (1), asthma (1) }\end{array}$ & None reported & [29] \\
\hline $\begin{array}{l}\text { Fifty-one } \\
\text { COVID-positive: } \\
\text { Eight women, } 43 \\
\text { men (from } 2873 \\
\text { HIV-positive } \\
\text { patients) }\end{array}$ & SARS-2 & $\begin{array}{l}\text { Common symptoms: } \\
\text { Non-productive cough, fever, } \\
\text { dyspnea, fatigue }\end{array}$ & $\begin{array}{c}\text { NRTIs (37), protease } \\
\text { inhibitor treatment (11) } \\
\text { hydroxychloroquine (30), } \\
\text { azithromycin (19), } \\
\text { ritonavir-boosted lopinavir } \\
\text { (14) - usually used in } \\
\text { combination, boosted } \\
\text { darunavir (8) }\end{array}$ & $\begin{array}{l}\text { Forty-four } \\
\text { recovered; } 2 \\
\text { fatalities }\end{array}$ & $\begin{array}{l}\text { Six-three percent } \\
\text { at least one } \\
\text { co-morbidity } \\
\text { (hypertension, } \\
\text { high BMI, diabetes, } \\
\text { chronic kidney } \\
\text { disease, chronic } \\
\text { liver disease) }\end{array}$ & None reported & [30] \\
\hline
\end{tabular}


Table 1. Cont

\begin{tabular}{|c|c|c|c|c|c|c|c|}
\hline Study Cohort & $\begin{array}{l}\mathrm{hCoV}(\% \\
\text { Incidence) }\end{array}$ & Clinical Presentation & $\begin{array}{l}\text { Other Types of Drugs } \\
\text { Administered (Number } \\
\text { Receiving the Drug) }\end{array}$ & $\begin{array}{l}\text { Disease Outcome } \\
\text { at the Time of } \\
\text { Reporting }\end{array}$ & Co-Morbidities & Other Pathogens & Reference \\
\hline $\begin{array}{l}\text { Eight patients } \\
\text { (from } 1174 \\
\text { HIV-positive } \\
\text { patients) }\end{array}$ & SARS-2 & $\begin{array}{l}\text { Low } \mathrm{CD}^{+} \text {counts }(2 / 8-100-350 \\
\left.\text { cells } / \mathrm{mm}^{3}\right) \text {, normal CD4 }{ }^{+} \text {counts } \\
\quad\left(6 / 8->350 \text { cells } / \mathrm{mm}^{3}\right)\end{array}$ & ARTs & One fatality & None reported & None reported & [31] \\
\hline $\begin{array}{l}\text { Four male patients } \\
\text { (from } 1224 \\
\text { HIV-positive } \\
\text { patients) }\end{array}$ & SARS-2 & $\begin{array}{l}\text { High HIV RNA load (3/4), low } \\
\text { CD4 }{ }^{+} \text {count, pneumonia, cough, } \\
\text { lymphocytopenia, elevated ferritin } \\
\text { levels }(1 / 4) \text {, elevated CRP levels } \\
(2 / 4) \text {, diarrhoea, thrombocytopenia }\end{array}$ & $\begin{array}{l}\text { ARTs } \\
\text { (NRTIs and protease } \\
\text { inhibitors), antibiotics }\end{array}$ & $\begin{array}{l}\text { Three recovered; } 1 \\
\text { fatality }\end{array}$ & $\begin{array}{l}\text { Bipolar disorder, } \\
\text { diabetes, COPD, } \\
\text { hypertension, } \\
\text { obesity }\end{array}$ & $\mathrm{HBV}$ & [32] \\
\hline $\begin{array}{l}\text { Forty-eight } \\
\text { HIV-positive (from } \\
5700 \text { COVID-19 } \\
\text { positive) }\end{array}$ & SARS-2 & None reported & None reported & None reported & None reported & & [35] \\
\hline $\begin{array}{l}\text { Thirty-eight-year-old } \\
\text { male }\end{array}$ & SARS-2 & $\begin{array}{c}\text { Fever, muscle aches, fever, } \\
\text { pneumonia, slightly elevated CRP } \\
\text { levels, normal WBC and } \\
\text { lymphocyte count }\end{array}$ & $\begin{array}{c}\text { ARTs } \\
\text { NRTIs, Oseltamivir, IFN- } \alpha\end{array}$ & Full recovery & None & $\mathrm{HCV}$ & [33] \\
\hline $\begin{array}{l}\text { Thirty-four-year-old } \\
\text { woman }\end{array}$ & SARS-2 & $\begin{array}{c}\text { gastrointestinal symptoms, } \\
\text { headache, chest pain, anorexia and } \\
\text { muscle aches }\end{array}$ & $\begin{array}{l}\text { Tenofovir disoproxil } \\
\text { fumarate, lamivudine and } \\
\text { efavirenz }\end{array}$ & Full recovery & None & None reported & [34] \\
\hline $\begin{array}{l}\text { Thirty-one } \\
\text { HIV-positive (from } \\
2159 \text { COVID-19 } \\
\text { positive patients) }\end{array}$ & SARS-2 & Fever viral pneumonia & $\begin{array}{c}\text { All patients were on ART; } \\
\text { integrase inhibitor-based } \\
\text { triple therapy } \\
\text { hydroxychloroquine (24), } \\
\text { azithromycin (16), } \\
\text { corticosteroids (8), IL-6R } \\
\text { antagonist tocilizumab (2), } \\
\text { antiviral drug-remdesivir } \\
\text { (1), IL-6R } \\
\text { inhibitor-sarilumab (1) }\end{array}$ & $\begin{array}{l}\text { Twenty-one } \\
\text { recovered; } 8 \\
\text { fatalities }\end{array}$ & $\begin{array}{c}\text { Seventy-one } \\
\text { percent at least one } \\
\text { co-morbidity } \\
\text { (hypertension, } \\
\text { diabetes mellitus, } \\
\text { obesity, asthma, } \\
\text { COPD }\end{array}$ & None Reported & [20] \\
\hline $\begin{array}{l}\text { Forty-seven } \\
\text { COVID-positive } \\
\text { (from 6,000 } \\
\text { HIV-positive } \\
\text { patients) }\end{array}$ & SARS-2 & $\begin{array}{l}\text { Fever, cough, dyspnea, diarrhea, } \\
\text { myalgia, headache }\end{array}$ & $\begin{array}{l}\text { Integrase inhibitor-based } \\
\text { ART; protease } \\
\text { inhibitor-based treatment; } \\
\text { tenofovir-based regime }\end{array}$ & $\begin{array}{l}\text { Forty-five } \\
\text { recovered; } 2 \\
\text { fatalities }\end{array}$ & $\begin{array}{l}\text { Sixty-four percent } \\
\text { at least one } \\
\text { co-morbidity } \\
\text { (dyslipidemia, } \\
\text { arterial } \\
\text { hypertension }\end{array}$ & $\mathrm{HBV}, \mathrm{HCV}$ & [36] \\
\hline Four male patients & SARS-2 & $\begin{array}{l}\text { Fatigue, loss of taste and smell, } \\
\text { fever, cough }\end{array}$ & All patients were on ART & Full recovery & $\begin{array}{l}\text { atrial fibrillation, } \\
\text { hyperlipidemia, } \\
\text { hypertension, type } \\
\text { II diabetes mellitus }\end{array}$ & $\begin{array}{c}\text { HCV (1) } \\
\text { influenza A (1) }\end{array}$ & [37] \\
\hline
\end{tabular}


To date, studies are reporting a COVID-19 prevalence of between $0.68 \%$ [31] and $1.8 \%$ [30] in HIV-positive patients. Similar to data for HIV-negative populations, old age and co-morbidities appear to be important in the development of severe COVID-19 and mortality in HIV-positive patients [29-31]. Interestingly, groups are now reporting that in HIV-positive patients, the gender, the CD4 ${ }^{+}$counts, the HIV viral load, or the ART regimen do not show a clear association with COVID-19 infection or severity of the disease [20,29-31]. It appears as though, as reported for immunocompetent individuals, that co-morbidities are an important factor in mortality rates in HIV/SARS-CoV-2 coinfections. Interestingly, others report, that COVID-19 disease prognosis is improved in HIV-positive patients that are on a regular ART regimen, and where HIV viral load is suppressed [32].

\section{CoV and HIV Induced Cytokine Storms}

Many viral infections trigger a hyperinflammatory syndrome, resulting in cytopenias, unremitting fever, and pulmonary involvement (including acute respiratory distress syndrome (ARDS)) in about half of patients [38]. A cytokine storm is typically characterized by a decrease in inhibitory cytokines (e.g., interleukin (IL)-10, transforming growth factor (TGF)- $\beta$ ), an increase in activation cytokines (e.g., IL-12, interferon (IFN)- $\gamma$, TNF- $\alpha$ ), and an increase in the infiltration of leukocytes into inflammatory sites [39].

In the majority of cases, HIV infection triggers an inflammatory response that presents as an acute retroviral syndrome. While this syndrome is normally self-limiting, primary HIV infection can, at times lead to a sudden and severe inflammatory process similar to cytokine storm syndrome $[40,41]$. Whereas, this increase in certain plasma cytokines and chemokines occurs very early after infection, cytokine storm is associated with acute HIV infection in the period leading up to peak viremia [41-43]. Importantly, the subsidence of the resultant cytokine storm is not complete, and if left untreated, some cytokines remain at higher than normal physiologic levels, which then persist into the chronic phase [43].

In severe lung infections, the cytokine storm-linked inflammatory response can move into the systemic circulation, producing systemic sepsis, which could result in damage of other organs $[39,44]$. Similarly, the three pathogenic hCoVs can also cause severe pneumonia, which is often associated with rapid virus replication, massive inflammatory cell infiltration and elevated pro-inflammatory cytokine/chemokine responses. This can then lead to acute lung injury (ALI), ARDS, and sometimes, death [14].

Both SARS-CoV- and MERS-CoV-linked severe disease is linked to an excessive immune response in the host, and cytokine dysregulation may account, at least partly, for the development of the severe clinical disease, ALI and ARDS [3]. SARS-CoV and MERS-CoV do not significantly stimulate the expression of certain antiviral cytokines (IFN- $\alpha$ and IFN- $\beta$ ), but do stimulate comparable levels of TNF- $\alpha$ and IL-6 [45]. In an in vitro Calu-3 cell system, the levels of expression of IL-1 $\beta$, IL- 6 and IL-8 were significantly higher in MERS-CoV infected cells than in SARS-CoV infected cells at $30 \mathrm{~h}$ post-infection. On the other hand, SARS-CoV induces markedly higher expression levels of TNF- $\alpha$, IFN- $\beta$ and IP (interferon gamma-induced protein)-10 in cells than MERS-CoV at 24 and $30 \mathrm{~h}$ [46]. This difference could possibly explain the difference in mortality rates reported for MERS and SARS. What could this look like?

Not only is an IFN- $\gamma$-related cytokine storm induced post-SARS-CoV infection [47-49], IP-10 and IL-2 are induced early in the infection. A subsequent over-production of IL-6, with a decreased production of IL-10, then likely leads to the main immunopathological damage involved in lung injury [50]. Severe pneumonia caused by MERS-CoV is also often associated with massive inflammatory cell infiltration and elevated pro-inflammatory cytokine/chemokine responses [14,45,46]. MERS-CoV induces the expression of high levels of IL-12, IFN- $\gamma$, and chemokines in the infected host [45].

Interestingly, a hyper-immune response is now also associated with severe COVID-19 [51]. Studies suggest that COVID-19-related mortality could also be linked to this virus-induced hyperinflammation [52], which is likely caused by a cytokine storm [53]. For severe COVID-19, 
the overproduction of early response proinflammatory cytokines (TNF, IL-6, and IL-1 $\beta$ ) results in this cytokine storm. This potentially leads to an increased risk of vascular hyperpermeability, multiorgan failure, and eventually, death when the high cytokine levels are not controlled [54,55]. Why are we not seeing more frequent severe CoV-related disease, including cytokine storms, in HIV-positive individuals?

\section{HIV-CoV Coinfections and Disease Outcome}

Van der Hoek et al. noted that in respiratory coinfections, the hCoV viral load is often much lower than for single infections [56]. Even though HIV is not a respiratory virus, this could explain why the $\mathrm{hCoV}$ viral load in HIV-positive patients seldomly researches the levels required for the severe coronavirus-related disease to develop.

Others are now hypothesizing that the disease outcomes seen in HIV-hCoV coinfection could be due to:

I. The existing infection with HIV-1 interfering with the replication of the CoV in the same host. This could result in the patient not being coinfected with the hCoV, or due to "viral interference" [15], the viral load of the hCoV remains low and severe coronavirus disease does not develop (see comments from [56] above); or

II. HAART, used in the treatment of patients with HIV-1/AIDS, interferes with CoV replication, thereby preventing the development of the severe coronavirus disease [27,57]; or

III. HIV induced lymphopenia could protect HIV-positive patients from severe CoV-disease clinical manifestations $[58,59]$.

Data from human and animal studies suggest that, after infection by unrelated pathogens, the host's immune response to subsequent infections can be altered. One virus competitively suppressing the replication of another coinfecting virus is one of the most common outcomes of coinfections [15]. Infections by certain heterologous viruses have been reported to result in protective cross-immunity by employing different processes, including innate immune activation [60], bystander protection by activated $\mathrm{CD}^{+}$or $\mathrm{CD}^{+} \mathrm{T}$ cells, and/or cross-reactive $\mathrm{CD} 8^{+} \mathrm{T}$ cells $[15,61]$.

IFN-mediated innate viral interference is the most common form of one virus suppressing the replication of another, heterologous virus [62]. When IFN binds to its cognate receptor, it results in the expression of multiple interferon-stimulated genes (ISGs), which in turn control and activates various cell signaling pathways [63-65]. The ISGs also control the actions of numerous innate immune mediators that are able to nonspecifically block virus replication [15]. This interference can occur at various steps of virus replication, including attachment [66], entry [67], genome replication [68,69], and budding $[15,70]$.

Immunity to previously encountered viruses that alters responses to unrelated pathogens is another common phenomenon amongst viruses and other microorganisms. One such example is heterologous immunity, where "exposure to one pathogen will generate an immune response against numerous antigenic epitopes derived from that pathogen, some of which might cross-react with epitopes derived from other pathogens." When a second, unrelated pathogen infects the host, the "cross-reactive memory cells expand more rapidly and may dominate the overall response" [71]. Another case where heterologous immunity is commonly observed is in persistently infected individuals who experience constant, low-level antigenic stimulation that alters their immunity to other pathogens [60]. In one study, mice are given a modified heat-labile bacterial toxin that altered the microenvironment, such that it improved the immune response to subsequent infection with RSV, influenza virus, or the fungus Cryptococcus neoformans. Interestingly, this type of protective immunity is partially $\mathrm{T}$ cell- and $\mathrm{B}$ cell-independent. Cytokines produced by activated antigen-presenting cells (APCs) stimulate T cells to differentiate into polarized subsets and influence the type of immune response that is generated to a second unrelated pathogen [72]. 
Interestingly, heterologous immunity can also lead to immunopathology, instead of protective immunity. One example of heterologous immunity, resulting in immunopathology, is observed in the immunopathologic features that become exaggerated and pronounced in young adults or the elderly (also observed in COVID-19), suggesting that prior infections in young adults-that have not yet occurred in most young children-may alter the immune environment to subsequent infections in the older patients $[17,73,74]$. The cytokine milieu elicited by the active infection seems to be what drives heterologous infections, and may modulate subsequent cellular responses $[17,75]$. Could this explain why we are seeing a more severe pathogenic $\mathrm{hCoV}$ infection is some older patients?

The reasons or mechanisms underlying the unexpected disease outcomes in $\mathrm{HIV} / \mathrm{hCoV}$ coinfections are unclear. Researchers are speculating that this could be explained by the anti-HIV agents having anti-CoV properties [5], or the initial HIV infection causing an alteration of host cells so that they no longer offer a favorable environment for virus replication and/or multiplication [33], a phenomenon reported previously by Beale [76]. Moreover, researchers have speculated that for SARS-CoV—but this could probably be for SARS-CoV-2 and MERS-CoV too-the defective cellular immunity in HIV-positive patients "could paradoxically be a protective factor in some patients" [26]; another group also hypothesize that for SARS-CoV-2 "the compromised immunity might be the reason that HIV/AIDS patients did not occur inflammatory changes and clinical symptoms" [31]. Mascolo et al. hypothesize that the absence of T-cell activation in the immunocompromised patient mitigates the severe immunopathological phenomena associated with COVID-19 [77]. Based on their own data, and data from others, Shalev et al. now speculate that even "uncontrolled HIV infection and poor $\mathrm{CD}^{+}{ }^{\mathrm{T}}$-cell function may limit SARS-CoV-2-related immune dysregulation and cytokine release" [20], offering some protection against the development of severe COVID-19.

\section{Conclusions}

In general, the risk associated with coinfections is still a matter of debate [78]. Therefore, with the lack of conclusive studies on HIV-CoV coinfections, researchers are concerned that the immune status that makes HIV-positive people vulnerable to other infections, could also predispose them to develop more severe $\mathrm{CoV}$ infections [58]. Furthermore, if we have evidence that HIV-positive people are more susceptible to develop more severe $\mathrm{hCoV}$-related diseases, it could lead to the early adoption of specific therapeutic strategies [24].

However, the estimated COVID-19 prevalence reported in various studies does not suggest increased rates of hospitalization or mortality in HIV-positive patient populations. Clinical characteristics and disease outcomes were comparable to those described for the general population with COVID-19 [20,30,35,36]. In conclusion, recent evidence points to the fact that, even in the HIV-positive community, pre-existing co-morbidities and old age place the individual at higher risk of developing a severe disease $[28,29,31]$. Interestingly, the type of HIV anti-viral drug used, or the HIV viral load does not appear to be determining factors [31,58]. The veracity of all of these claims needs to be confirmed, however.

Author Contributions: Conceptualization: B.C.F.; original draft preparation: P.M. and B.C.F.; review and editing: P.M. and B.C.F. All authors have read and agreed to the published version of the manuscript.

Funding: P.M. receives funding from Poliomyelitis Research Fund (PRF) and the National Research Foundation (NRF) (South Africa). B.C.F. receives funding from the National Research Foundation (NRF) (South Africa). Any opinion, findings and conclusions or recommendations expressed in this material are those of the authors, and therefore, the NRF does not accept any liability in regard thereto.

Acknowledgments: The authors apologize to any author whose work has been inadvertently omitted from this review article.

Conflicts of Interest: The authors declare no conflict of interest. The funders had no role in the design of the study; in the collection, analyses, or interpretation of data; in the writing of the manuscript, or in the decision to publish the results. 


\section{References}

1. Berry, M.; Gamieldien, J.; Fielding, B.C. Identification of new respiratory viruses in the new millennium. Viruses 2015, 7, 996-1019. [CrossRef] [PubMed]

2. Debiaggi, M.; Canducci, F.; Ceresola, E.R.; Clementi, M. The role of infections and coinfections with newly identified and emerging respiratory viruses in children. Virol. J. 2012, 9, 247. [CrossRef] [PubMed]

3. Sloots, T.P.; Whiley, D.M.; Lambert, S.B.; Nissen, M.D. Emerging respiratory agents: New viruses for old diseases? J. Clin. Virol. 2008, 42, 233-243. [CrossRef] [PubMed]

4. Shah, A.; Kashyap, R.; Tosh, P.; Sampathkumar, P.; O'Horo, J.C. Guide to Understanding the 2019 Novel Coronavirus. Mayo Clin. Proc. 2020. [CrossRef] [PubMed]

5. Wang, W.; Tang, J.; Wei, F. Updated understanding of the outbreak of 2019 novel coronavirus (2019-nCoV) in Wuhan, China. J. Med. Virol. 2020, 92, 441-447. [CrossRef]

6. Tyrrell, D.A.; Bynoe, M.L. Cultivation of a Novel Type of Common-Cold Virus in Organ Cultures. Br. Med. J. 1965, 1, 1467-1470. [CrossRef]

7. Hamre, D.; Procknow, J.J. A new virus isolated from the human respiratory tract. Proc. Soc. Exp. Biol. Med. 1966, 121, 190-193. [CrossRef]

8. $\quad$ Peiris, J.S.; Lai, S.T.; Poon, L.L.; Guan, Y.; Yam, L.Y.; Lim, W.; Nicholls, J.; Yee, W.K.; Yan, W.W.; Cheung, M.T.; et al. Coronavirus as a possible cause of severe acute respiratory syndrome. Lancet 2003, 361, 1319-1325. [CrossRef]

9. Van der Hoek, L.; Pyrc, K.; Jebbink, M.F.; Vermeulen-Oost, W.; Berkhout, R.J.; Wolthers, K.C.; Wertheim-van Dillen, P.M.; Kaandorp, J.; Spaargaren, J.; Berkhout, B. Identification of a new human coronavirus. Nat. Med. 2004, 10, 368-373. [CrossRef]

10. Woo, P.C.; Lau, S.K.; Chu, C.M.; Chan, K.H.; Tsoi, H.W.; Huang, Y.; Wong, B.H.; Poon, R.W.; Cai, J.J.; Luk, W.K.; et al. Characterization and complete genome sequence of a novel coronavirus, coronavirus HKU1, from patients with pneumonia. J. Virol. 2005, 79, 884-895. [CrossRef]

11. Lu, G.; Liu, D. SARS-like virus in the Middle East: A truly bat-related coronavirus causing human diseases. Protein Cell 2012, 3, 803-805. [CrossRef] [PubMed]

12. Bermingham, A.; Chand, M.A.; Brown, C.S.; Aarons, E.; Tong, C.; Langrish, C.; Hoschler, K.; Brown, K.; Galiano, M.; Myers, R.; et al. Severe respiratory illness caused by a novel coronavirus, in a patient transferred to the United Kingdom from the Middle East, September 2012. Eurosurveillance 2012, 17, 20290.

13. Van der Hoek, L. Human coronaviruses: What do they cause? Antivir. Ther. 2007, 12, 651-658. [PubMed]

14. Channappanavar, R.; Perlman, S. Pathogenic human coronavirus infections: Causes and consequences of cytokine storm and immunopathology. Semin. Immunopathol. 2017, 39, 529-539. [CrossRef] [PubMed]

15. Kumar, N.; Sharma, S.; Barua, S.; Tripathi, B.N.; Rouse, B.T. Virological and Immunological Outcomes of Coinfections. Clin. Microbiol. Rev. 2018, 31. [CrossRef] [PubMed]

16. Salas-Benito, J.S.; De Nova-Ocampo, M. Viral Interference and Persistence in Mosquito-Borne Flaviviruses. J. Immunol. Res. 2015, 2015, 873404. [CrossRef]

17. Sharma, S.; Thomas, P.G. The two faces of heterologous immunity: Protection or immunopathology. J. Leukoc. Biol. 2014, 95, 405-416. [CrossRef]

18. Waner, J.L. Mixed viral infections: Detection and management. Clin. Microbiol. Rev. 1994, 7, $143-151$. [CrossRef]

19. Redd, A.D.; Quinn, T.C.; Tobian, A.A. Frequency and implications of HIV superinfection. Lancet Infect. Dis. 2013, 13, 622-628. [CrossRef]

20. Shalev, N.; Scherer, M.; LaSota, E.D.; Antoniou, P.; Yin, M.T.; Zucker, J.; Sobieszczyk, M.E. Clinical characteristics and outcomes in people living with HIV hospitalized for COVID-19. Clin. Infect. Dis. 2020. [CrossRef]

21. Eis-Hubinger, A.M.; Stifter, G.; Schneweis, K.E. Opportunistic infections with coronavirus-like particles in patients infected with the human immunodeficiency virus? Zent. Bakteriol. 1989, 271, 351-355. [CrossRef]

22. Kern, P.; Muller, G.; Schmitz, H.; Racz, P.; Meigel, W.; Riethmuller, G.; Dietrich, M. Detection of coronavirus-like particles in homosexual men with acquired immunodeficiency and related lymphadenopathy syndrome. Klin. Wochenschr. 1985, 63, 68-72. [CrossRef] [PubMed]

23. Macconnachie, A.A.; Collins, T.C.; Seaton, R.A.; Kennedy, D.H. Three men, a paint brush and a coronavirus. Int. J. STD AIDS 2007, 18, 132-133. [CrossRef] [PubMed] 
24. Villamil-Gomez, W.E.; Sanchez, A.; Gelis, L.; Silvera, L.A.; Barbosa, J.; Otero-Nader, O.; Bonilla-Salgado, C.D.; Rodriguez-Morales, A.J. Fatal human coronavirus 229E (HCoV-229E) and RSV-Related pneumonia in an AIDS patient from Colombia. Travel Med. Infect. Dis. 2020, 101573. [CrossRef]

25. Nunes, M.C.; Kuschner, Z.; Rabede, Z.; Madimabe, R.; Van Niekerk, N.; Moloi, J.; Kuwanda, L.; Rossen, J.W.; Klugman, K.P.; Adrian, P.V.; et al. Clinical epidemiology of bocavirus, rhinovirus, two polyomaviruses and four coronaviruses in HIV-infected and HIV-uninfected South African children. PLoS ONE 2014, 9, e86448. [CrossRef]

26. Wong, A.T.; Tsang, O.T.; Wong, M.Y.; Lim, W.L.; Zheng, B.J.; Lee, S.S.; Lai, S.T.; Yuen, K.Y.; Choi, K.W.; Tso, E.Y.; et al. Coronavirus infection in an AIDS patient. AIDS 2004, 18, 829-830. [CrossRef]

27. Chen, X.P.; Cao, Y. Consideration of highly active antiretroviral therapy in the prevention and treatment of severe acute respiratory syndrome. Clin. Infect. Dis 2004, 38, 1030-1032. [CrossRef]

28. Zhu, F.; Cao, Y.; Xu, S.; Zhou, M. Co-infection of SARS-CoV-2 and HIV in a patient in Wuhan city, China. J. Med. Virol. 2020. [CrossRef]

29. Blanco, J.L.; Ambrosioni, J.; Garcia, F.; Martinez, E.; Soriano, A.; Mallolas, J.; Miro, J.M.; Investigators, C.-i.H. COVID-19 in patients with HIV: Clinical case series. Lancet HIV 2020. [CrossRef]

30. Vizcarra, P.; Perez-Elias, M.J.; Quereda, C.; Moreno, A.; Vivancos, M.J.; Dronda, F.; Casado, J.L.; Team, C.-I. Description of COVID-19 in HIV-infected individuals: A single-centre, prospective cohort. Lancet HIV 2020. [CrossRef]

31. Guo, W.; Ming, F.; Dong, Y.; Zhang, Q.; Zhang, X.; Mo, P.; Feng, Y.; Liang, K. A Survey for COVID-19 Among HIV/AIDS Patients in Two Districts of Wuhan, China (3/4/2020). Available online: https://ssrn.com/abstract= 3550029 (accessed on 28 April 2020).

32. Aydin, O.A.; Karaosmanoglu, H.K.; Yasar, K.K. HIV/SARS-CoV-2 coinfected patients in Istanbul, Turkey. J. Med. Virol. 2020. [CrossRef]

33. Zhao, J.; Liao, X.; Wang, H.; Wei, L.; Xing, M.; Liu, L.; Zhang, Z. Early virus clearance and delayed antibody response in a case of COVID-19 with a history of co-infection with HIV-1 and HCV. Clin. Infect. Dis. 2020. [CrossRef]

34. Baluku, J.B.; Mwebaza, S.; Ingabire, G.; Nsereko, C.; Muwanga, M. HIV and SARS-CoV-2 coinfection: A case report from Uganda. J. Med. Virol. 2020. [CrossRef] [PubMed]

35. Richardson, S.; Hirsch, J.S.; Narasimhan, M.; Crawford, J.M.; McGinn, T.; Davidson, K.W.; Northwell, C.-R.C.; Barnaby, D.P.; Becker, L.B.; Chelico, J.D.; et al. Presenting Characteristics, Comorbidities, and Outcomes Among 5700 Patients Hospitalized With COVID-19 in the New York City Area. JAMA 2020. [CrossRef] [PubMed]

36. Gervasoni, C.; Meraviglia, P.; Riva, A.; Giacomelli, A.; Oreni, L.; Minisci, D.; Atzori, C.; Ridolfo, A.; Cattaneo, D. Clinical features and outcomes of HIV patients with coronavirus disease 2019. Clin. Infect. Dis. 2020. [CrossRef]

37. Benkovic, S.; Kim, M.; Sin, E. Four cases: Human immunodeficiency virus and novel coronavirus 2019 Co-infection in patients from Long Island, New York. J. Med. Virol. 2020. [CrossRef]

38. Seguin, A.; Galicier, L.; Boutboul, D.; Lemiale, V.; Azoulay, E. Pulmonary Involvement in Patients With Hemophagocytic Lymphohistiocytosis. Chest 2016, 149, 1294-1301. [CrossRef]

39. Tisoncik, J.R.; Korth, M.J.; Simmons, C.P.; Farrar, J.; Martin, T.R.; Katze, M.G. Into the eye of the cytokine storm. Microbiol. Mol. Biol. Rev. 2012, 76, 16-32. [CrossRef]

40. Pastor, L.; Casellas, A.; Carrillo, J.; Alonso, S.; Parker, E.; Fuente-Soro, L.; Jairoce, C.; Mandomando, I.; Blanco, J.; Naniche, D. IP-10 Levels as an Accurate Screening Tool to Detect Acute HIV Infection in Resource-Limited Settings. Sci. Rep. 2017, 7, 8104. [CrossRef]

41. Stacey, A.R.; Norris, P.J.; Qin, L.; Haygreen, E.A.; Taylor, E.; Heitman, J.; Lebedeva, M.; DeCamp, A.; Li, D.; Grove, D.; et al. Induction of a striking systemic cytokine cascade prior to peak viremia in acute human immunodeficiency virus type 1 infection, in contrast to more modest and delayed responses in acute hepatitis B and C virus infections. J. Virol. 2009, 83, 3719-3733. [CrossRef]

42. Erdmann, N.; Heath, S.L. Cytokine Storm Syndrome as a Manifestation of Primary HIV Infection. In Cytokine Storm Syndrome; Cron, R., Behrens, E., Eds.; Springer: Cham, Switzerland, 2019; pp. 299-306. [CrossRef]

43. Muema, D.M.; Akilimali, N.A.; Ndumnego, O.C.; Rasehlo, S.S.; Durgiah, R.; Ojwach, D.B.A.; Ismail, N.; Dong, M.; Moodley, A.; Dong, K.L.; et al. Association between the cytokine storm, immune cell dynamics, and viral replicative capacity in hyperacute HIV infection. BMC Med. 2020, 18, 81. [CrossRef] [PubMed] 
44. Ramos-Casals, M.; Brito-Zeron, P.; Lopez-Guillermo, A.; Khamashta, M.A.; Bosch, X. Adult haemophagocytic syndrome. Lancet 2014, 383, 1503-1516. [CrossRef]

45. Zhou, J.; Chu, H.; Li, C.; Wong, B.H.; Cheng, Z.S.; Poon, V.K.; Sun, T.; Lau, C.C.; Wong, K.K.; Chan, J.Y.; et al. Active replication of Middle East respiratory syndrome coronavirus and aberrant induction of inflammatory cytokines and chemokines in human macrophages: Implications for pathogenesis. J. Infect. Dis. 2014, 209, 1331-1342. [CrossRef] [PubMed]

46. Lau, S.K.P.; Lau, C.C.Y.; Chan, K.H.; Li, C.P.Y.; Chen, H.; Jin, D.Y.; Chan, J.F.W.; Woo, P.C.Y.; Yuen, K.Y. Delayed induction of proinflammatory cytokines and suppression of innate antiviral response by the novel Middle East respiratory syndrome coronavirus: Implications for pathogenesis and treatment. J. Gen. Virol. 2013, 94, 2679-2690. [CrossRef]

47. Huang, K.J.; Su, I.J.; Theron, M.; Wu, Y.C.; Lai, S.K.; Liu, C.C.; Lei, H.Y. An interferon-gamma-related cytokine storm in SARS patients. J. Med. Virol. 2005, 75, 185-194. [CrossRef]

48. Wong, C.K.; Lam, C.W.; Wu, A.K.; Ip, W.K.; Lee, N.L.; Chan, I.H.; Lit, L.C.; Hui, D.S.; Chan, M.H.; Chung, S.S.; et al. Plasma inflammatory cytokines and chemokines in severe acute respiratory syndrome. Clin. Exp. Immunol. 2004, 136, 95-103. [CrossRef]

49. Chen, J.; Subbarao, K. The Immunobiology of SARS*. Annu. Rev. Immunol. 2007, 25, 443-472. [CrossRef]

50. Chien, J.Y.; Hsueh, P.R.; Cheng, W.C.; Yu, C.J.; Yang, P.C. Temporal changes in cytokine/chemokine profiles and pulmonary involvement in severe acute respiratory syndrome. Respirology 2006, 11, 715-722. [CrossRef]

51. Huang, C.; Wang, Y.; Li, X.; Ren, L.; Zhao, J.; Hu, Y.; Zhang, L.; Fan, G.; Xu, J.; Gu, X.; et al. Clinical features of patients infected with 2019 novel coronavirus in Wuhan, China. Lancet 2020, 395, 497-506. [CrossRef]

52. Mehta, P.; McAuley, D.F.; Brown, M.; Sanchez, E.; Tattersall, R.S.; Manson, J.J.; Hlh Across Speciality Collaboration, U.K. COVID-19: Consider cytokine storm syndromes and immunosuppression. Lancet 2020. [CrossRef]

53. Chen, C.; Zhang, X.; Ju, Z.; He, W. New coronavirus pneumonia caused cytokine storm mechanism and related immunotherapy research progress. Chin. J. Burn. 2020, 36. [CrossRef]

54. Jose, R.J.; Manuel, A. COVID-19 cytokine storm: The interplay between inflammation and coagulation. Lancet Respir. Med. 2020. [CrossRef]

55. Ye, Q.; Wang, B.; Mao, J. The pathogenesis and treatment of the 'Cytokine Storm' in COVID-19. J. Infect. 2020. [CrossRef]

56. Van der Hoek, L.; Pyrc, K.; Berkhout, B. Human coronavirus NL63, a new respiratory virus. FEMS Microbiol. Rev. 2006, 30, 760-773. [CrossRef] [PubMed]

57. Chen, X.P.; Li, G.H.; Tang, X.P.; Xiong, Y.; Chen, X.J.; Cao, Y. Lack of severe acute respiratory syndrome in 19 AIDS patients hospitalized together. J. Acquir. Immune Defic. Syndr. 2003, 34, 242-243. [CrossRef]

58. Cornberg, M.; Kenney, L.L.; Chen, A.T.; Waggoner, S.N.; Kim, S.K.; Dienes, H.P.; Welsh, R.M.; Selin, L.K. Clonal exhaustion as a mechanism to protect against severe immunopathology and death from an overwhelming CD8 T cell response. Front. Immunol. 2013, 4, 475. [CrossRef] [PubMed]

59. Romanelli, A.; Mascolo, S. Immunosuppression drug-related and clinical manifestation of Coronavirus disease 2019: A therapeutical hypothesis. Am. J. Transplant. 2020. [CrossRef]

60. Barton, E.S.; White, D.W.; Cathelyn, J.S.; Brett-McClellan, K.A.; Engle, M.; Diamond, M.S.; Miller, V.L.; Virgin, H.W.T. Herpesvirus latency confers symbiotic protection from bacterial infection. Nature 2007, 447, 326-329. [CrossRef]

61. Che, J.W.; Daniels, K.A.; Selin, L.K.; Welsh, R.M. Heterologous Immunity and Persistent Murine Cytomegalovirus Infection. J. Virol. 2017, 91. [CrossRef]

62. Haller, O. Jean Lindenmann: From viral interference to interferon and beyond (1924-2015). J. Interferon Cytokine Res. 2015, 35, 239-241. [CrossRef]

63. Tan, K.S.; Olfat, F.; Phoon, M.C.; Hsu, J.P.; Howe, J.L.C.; Seet, J.E.; Chin, K.C.; Chow, V.T.K. In vivo and in vitro studies on the antiviral activities of viperin against influenza H1N1 virus infection. J. Gen. Virol. 2012, 93, 1269-1277. [CrossRef] [PubMed]

64. Birdwell, L.D.; Zalinger, Z.B.; Li, Y.; Wright, P.W.; Elliott, R.; Rose, K.M.; Silverman, R.H.; Weiss, S.R. Activation of RNase L by Murine Coronavirus in Myeloid Cells Is Dependent on Basal Oas Gene Expression and Independent of Virus-Induced Interferon. J. Virol. 2016, 90, 3160-3172. [CrossRef] 
65. Streitenfeld, H.; Boyd, A.; Fazakerley, J.K.; Bridgen, A.; Elliott, R.M.; Weber, F. Activation of PKR by Bunyamwera virus is independent of the viral interferon antagonist NSs. J. Virol. 2003, 77, 5507-5511. [CrossRef] [PubMed]

66. Benson, R.E.; Sanfridson, A.; Ottinger, J.S.; Doyle, C.; Cullen, B.R. Downregulation of cell-surface CD4 expression by simian immunodeficiency virus Nef prevents viral super infection. J. Exp. Med. 1993, 177, 1561-1566. [CrossRef] [PubMed]

67. Singh, I.R.; Suomalainen, M.; Varadarajan, S.; Garoff, H.; Helenius, A. Multiple mechanisms for the inhibition of entry and uncoating of superinfecting Semliki Forest virus. Virology 1997, 231, 59-71. [CrossRef] [PubMed]

68. Schaller, T.; Appel, N.; Koutsoudakis, G.; Kallis, S.; Lohmann, V.; Pietschmann, T.; Bartenschlager, R. Analysis of hepatitis $\mathrm{C}$ virus superinfection exclusion by using novel fluorochrome gene-tagged viral genomes. J. Virol. 2007, 81, 4591-4603. [CrossRef]

69. Claus, C.; Tzeng, W.P.; Liebert, U.G.; Frey, T.K. Rubella virus-induced superinfection exclusion studied in cells with persisting replicons. J. Gen. Virol. 2007, 88, 2769-2773. [CrossRef]

70. Beperet, I.; Irons, S.L.; Simon, O.; King, L.A.; Williams, T.; Possee, R.D.; Lopez-Ferber, M.; Caballero, P. Superinfection exclusion in alphabaculovirus infections is concomitant with actin reorganization. J. Virol. 2014, 88, 3548-3556. [CrossRef]

71. Rouse, B.T.; Sehrawat, S. Immunity and immunopathology to viruses: What decides the outcome? Nat. Rev. Immunol. 2010, 10, 514-526. [CrossRef]

72. Williams, A.E.; Edwards, L.; Humphreys, I.R.; Snelgrove, R.; Rae, A.; Rappuoli, R.; Hussell, T. Innate imprinting by the modified heat-labile toxin of Escherichia coli (LTK63) provides generic protection against lung infectious disease. J. Immunol. 2004, 173, 7435-7443. [CrossRef]

73. Huster, K.M.; Stemberger, C.; Gasteiger, G.; Kastenmuller, W.; Drexler, I.; Busch, D.H. Cutting edge: Memory CD8 $\mathrm{T}$ cell compartment grows in size with immunological experience but nevertheless can lose function. J. Immunol. 2009, 183, 6898-6902. [CrossRef] [PubMed]

74. Vezys, V.; Yates, A.; Casey, K.A.; Lanier, G.; Ahmed, R.; Antia, R.; Masopust, D. Memory CD8 T-cell compartment grows in size with immunological experience. Nature 2009, 457, 196-199. [CrossRef] [PubMed]

75. Cicin-Sain, L.; Brien, J.D.; Uhrlaub, J.L.; Drabig, A.; Marandu, T.F.; Nikolich-Zugich, J. Cytomegalovirus infection impairs immune responses and accentuates T-cell pool changes observed in mice with aging. PLoS Pathog. 2012, 8, e1002849. [CrossRef] [PubMed]

76. Beale, A.J. Viral interference and interferon. Annu. Rev. Med. 1963, 14, 133-140. [CrossRef]

77. Mascolo, S.; Romanelli, A.; Carleo, M.A.; Esposito, V. Could HIV infection alter the clinical course of SARS-CoV-2 infection? When less is better. J. Med. Virol. 2020. [CrossRef]

78. Alfaraj, S.H.; Al-Tawfiq, J.A.; Alzahrani, N.A.; Altwaijri, T.A.; Memish, Z.A. The impact of co-infection of influenza A virus on the severity of Middle East Respiratory Syndrome Coronavirus. J. Infect. 2017, 74, 521-523. [CrossRef]

(C) 2020 by the authors. Licensee MDPI, Basel, Switzerland. This article is an open access article distributed under the terms and conditions of the Creative Commons Attribution (CC BY) license (http://creativecommons.org/licenses/by/4.0/). 